\title{
Sensory Descriptive Profiling and Consumer Acceptance of Made-in-transit (MIT) Set Yoghurt
}

\author{
M. A. R. Nor-Khaizura ${ }^{1,2}$, S. H. Flint ${ }^{1}$, O. J. McCarthy ${ }^{1}$, S. W. Tay ${ }^{1} \&$ J. Grigor ${ }^{3}$ \\ ${ }^{1}$ Institute Food, Nutrition and Human Health, Massey University, Private Bag 11 222, Palmerston North 4442, \\ New Zealand \\ ${ }^{2}$ Faculty of Food Science and Technology, Universiti Putra Malaysia, 43400 Serdang Selangor, Malaysia \\ ${ }^{3}$ Institute Food, Nutrition and Human Health, Massey University, Auckland, New Zealand \\ Correspondence: M. A. R. Nor-Khaizura, Faculty of Food Science and Technology, Universiti Putra Malaysia, \\ 43400 Serdang Selangor, Malaysia. Tel: 603-8946-8533. E-mail: norkhaizura@upm.edu.my
}

\author{
Received: February 14, $2018 \quad$ Accepted: February 28, $2018 \quad$ Online Published: April 6, 2018 \\ doi:10.5539/jfr.v7n3p82 URL: https://doi.org/10.5539/jfr.v7n3p82
}

\begin{abstract}
Shelf-life loss during the distribution of food is a growing problem for the food industry as manufacturers centralize production into large manufacturing units and expand their markets. Adaptation of made-in-transit (MIT) concept that changes the transportation of food from merely relocating products to a productive system would permit production during distribution. This concept could maximize product shelf-life and providing the consumer with the freshest product. Alteration of some yoghurt processing parameters (e.g. milk base, heat treatment, starter culture concentration and fermentation temperature) was able make the yoghurt suitable for an MIT product. Therefore, this work is to determine the sensory characteristic of two manufacturing methods for MIT set yoghurt. Manufacturing method (1) consisted of a skim milk base fortified with milk protein concentrate (MPC) inoculated with a $0.2 \%(\mathrm{v} / \mathrm{v})$ inoculum of $S$. thermophilus STM5 and L. acidophilus LA5 (STLA) in a ratio of 1:1. Manufacturing method (2) consisted of a skim milk base fortified with sodium caseinate $(\mathrm{NaCN})$ inoculated with a $0.002 \%(\mathrm{v} / \mathrm{v})$ inoculum of STLA. In both manufacturing methods, fermentation was at $25^{\circ} \mathrm{C}$ for $168 \mathrm{~h}$. Sensory evaluation of the yoghurts manufactured by each method was compared with standard set yoghurt. There were no significant differences $(p>0.05)$ between the two MIT set yoghurts on sensory evaluation (descriptive test) yet they were significantly different $(\mathrm{p}<0.05)$ to the standard set yoghurt. MIT set yoghurts scored better than standard set yoghurt for overall acceptance.
\end{abstract}

Keywords: yoghurt, made-in-transit, descriptive test, acceptance test

\section{Introduction}

Made in transit (MIT) is defined as a supply chain concept in which the production or manufacture of a perishable food occurs partially or completely during transportation (Nor-Khaizura et al., 2014, Jaworska, 2007). The MIT concept transforms manufacture where manufacture is merged with distribution. This has the potential to change the role of transportation from simply relocating material to include manufacture. Potential foods most suited to MIT are fermented products like cheese, salami, fermented drinks and yoghurt. Modification of some yoghurt processing parameters (e.g. milk base, heat treatment, starter culture concentration and fermentation temperature) was able to make the yoghurt suitable for an MIT product. However, the quality and acceptance of yoghurt depends upon the flavor and texture of the product (Soukoulis, et al., 2007). This two attributes are affected by the milk base composition (Rohm, 1993), heat treatment (Soukoulis, et al., 2007), starter culture and fermentation temperature (Tamime \& Robinson, 2007).

The milk base composition is likely to have the greatest effect on yoghurt texture. Fortification of the skim milk base with milk protein concentrate (MPC) or sodium caseinate $(\mathrm{NaCN})$ improves the firmness of yoghurt, and syneresis decreases as the protein content increases (Nor-Khaizura et al., 2012, Schkoda, Hechler, \& Hinrichs, 2001). Soukoulis et al. (2007) found yoghurt fortified with MPC produced a product with a better texture than that produced through the addition of whey protein. Isleten and Karagul-Yuceer (2006) and Nor-Khaizura et al. (2012) reported that yogurts fortified with $\mathrm{NaCN}$ exhibited better physical and sensory properties than control yoghurts. Yoghurts made with other casein-based ingredients were found firmer, with less syneresis, than 
yoghurts that were fortified at the same protein level with whey protein-based ingredients (Modler et al., 1983). The objective of this study was to evaluate the sensory characteristics of two MIT set yoghurts produced using two formulations: skim milk base fortified with (1) MPC and (2) NaCN.

\section{Materials and Methods}

\subsection{Experimental Design}

An experiment was carried out to study the sensory characteristics of two set yoghurts compared with standard yoghurt. Yoghurt was manufactured with three different formulations (Table 1). Sensory evaluation was carried out after the final yoghurt had been stored at 4 to $6^{\circ} \mathrm{C}$ for $48 \mathrm{~h}$.

\subsection{Cultures}

The lactic acid starter bacteria used were S. thermophilus STM5 (ST) and L. acidophilus LA5 (LA) supplied freeze dried and L. delbrueki subsp. bulgaricus supplied frozen, by the Fonterra Research Centre (Palmerston North, New Zealand). The cultures were activated twice in skim milk media (10\% w/v skim milk in distilled water, sterilized at $110^{\circ} \mathrm{C}$ for $10 \mathrm{~min}$ ) at $37{ }^{\circ} \mathrm{C}$ for $18 \mathrm{~h}$ before use. This procedure produced a consistent concentration of starter culture within $\log 10^{8} \mathrm{CFU} \mathrm{ml}^{-1}$ in each starter bacteria: $8.75 \pm 0.63 \log \mathrm{cfu} \mathrm{mL}^{-1}(\log$ colony forming units $\mathrm{mL}^{-1}$ ) for $S$. thermophilus STM5, $8.30 \pm 0.75 \log \mathrm{cfu} \mathrm{mL} \mathrm{m}^{-1}$ for L. acidophilus

Table 1. Set yoghurt formulations and processing conditions

\begin{tabular}{lllll}
\hline Formulation & Fortifying material & $\begin{array}{l}\text { Starter culture } \\
\text { composition }^{\text {Inoculum size }}\end{array}$ & $\begin{array}{l}\text { Fermentation } \\
(\%(\mathbf{v} / \mathbf{v}))\end{array}$ & $\begin{array}{l}\text { temperature }\left({ }^{\circ} \mathbf{C}\right) \\
\text { tem }\end{array}$ \\
\hline 1 & Milk protein concentrate (MPC) & STLA $^{\mathrm{a}}$ & $0.2 \%$ & $25^{\circ} \mathrm{C}$ \\
2 & Sodium caseinate $(\mathrm{NaCN})$ & STLA $^{\mathrm{b}}$ & $0.002 \%$ & $25^{\circ} \mathrm{C}$ \\
Standard yoghurt & None & STLB $^{\mathrm{b}}$ & $2.0 \%$ & $42^{\circ} \mathrm{C}$ \\
\hline
\end{tabular}

${ }^{\mathrm{a}}$ S. thermophilus STM5 and L. acidophilus LA5 ${ }^{\mathrm{b}}$ S. thermophilus STM5 and L. bulgaricus

LA5 and $8.27 \pm 0.35 \log$ cfu $\mathrm{mL}^{-1}$ for L. bulgaricus confirmed by plate counting. A 1:1 mixture of STLA was then used as a combined starter culture at a level in the milk base of $0.2 \%$ and $0.002 \%(\mathrm{v} / \mathrm{v})$ for MIT yoghurt, while a 1:1 mixture of STLB at 2.0\% (v/v) inoculum size was used for standard yoghurt.

\subsection{Preparation and Fortification of the Yoghurt Milk Base}

Skim milk powder (SMP) was obtained from Fonterra (Fonterra Co-operative Group, New Zealand). The typical composition of SMP is as follows: lactose $54.1 \%$, protein $33.4 \%$, minerals $7.9 \%$, moisture $3.8 \%$ and fat $0.8 \%$. Experimental yoghurt milk bases were prepared using reconstituted skim milk powder $(4.0 \%$ protein $(\mathrm{w} / \mathrm{v}))$ fortified with MPC or $\mathrm{NaCN}$ to bring the final protein content to $5.0 \%(\mathrm{w} / \mathrm{v})$. For the standard set yoghurt, the milk base contained only SMP. The dried ingredients were mixed and reconstituted in distilled water with agitation using a magnetic stirring unit (Heidolph MR 3001) for $3 \mathrm{~h}$ at $25^{\circ} \mathrm{C}$ (Lee \& Lucey, 2004). This reconstitution method is a gentle process and does not significantly damage the casein micelles compared with high shear and/or homogenization processes (Bock et al. 2008). The milk bases were stored in a refrigerator $\left(4^{\circ} \mathrm{C}\right)$ overnight before use (Lee \& Lucey, 2004).

\subsection{Heat Treatment of Milk Base}

The reconstituted skim milk was taken from the refrigerator and transferred to the Institute of Food, Nutrition and Human Health (IFNHH) Pilot Plant for ultra-high-temperature (UHT) processing using an indirect UHT plant (Alfa Laval, Lund, Sweden). Prior to an experimental run, the plant was pre-sterilized by circulating water at $120^{\circ} \mathrm{C}$ outlet temperature for $1 \mathrm{~h}$ and by treating the milk collection area with UV light. The holding temperature was set at $138^{\circ} \mathrm{C}$ and the flow rate at $0.833 \mathrm{~L} \mathrm{~min}^{-1}$ to obtain a holding time of $6 \mathrm{~s}$. These UHT conditions, $138^{\circ} \mathrm{C}$ for $6 \mathrm{~s}$, are based on a previous study by Schmidt et al. (1985). The UHT milk was collected by hand aseptically into sterile Schott Duran bottles at $6-10^{\circ} \mathrm{C}$ in a laminar flow cabinet.

The yoghurt milk base for standard set yoghurt was subjected to a high-temperature long-time (HTLT) heat treatment $\left(90^{\circ} \mathrm{C}\right.$ for $\left.30 \mathrm{~min}\right)$. This treatment was carried out batch wise using a temperature controlled water bath (Model ED, Julabo Labortechnik GMBH Germany). The treated milk was dispensed into sterile Schott Duran bottles (autoclaved at $121^{\circ} \mathrm{C}$ for $15 \mathrm{~min}$ ) and stored at $4{ }^{\circ} \mathrm{C}$ until used for yoghurt making.

\subsection{Yoghurt Processing}

Yoghurt manufacture was carried out in the Massey University IFNHH Product Development Lab. The milk was taken from the refrigerator and allowed to come to the fermentation temperature $\left(\sim 25^{\circ} \mathrm{C}\right.$ for MIT set yoghurt and 
$\sim 42^{\circ} \mathrm{C}$ for standard set yoghurt) in an incubator. The UHT milk base was then inoculated with 0.2 and $0.002 \%$ (v/v) starter culture at ratio 1:1 of S. thermophilus STM5 and L. acidophilus LA5 (STLA) for milk bases fortified with MPC and $\mathrm{NaCN}$, respectively. The HTLT treated milk for standard set yoghurt was inoculated with $2.0 \%$ (v/v) of a starter culture of Streptococcus thermophilus STM5 and Lactobacillus delbrueki subsp. bulgaricus in the ratio 1:1 (STLB). The milk base was shaken manually for $60 \mathrm{~s}$ and left in the fermentation bottle for $10 \mathrm{~min}$ after inoculation before being poured into sterile plastic containers $(55 \mathrm{~mm}$ height; $40 \mathrm{~mm}$ diameter) (LabServ, Auckland, New Zealand). The containers were filled to a headspace of approximately $4.0 \mathrm{~cm}$ (sample volume $\approx$ $50 \mathrm{~mL}$ ). The containers were then sealed with screw lids and placed in an incubator set at the fermentation temperature of $25^{\circ} \mathrm{C}$ for of MIT set yoghurt and $42^{\circ} \mathrm{C}$ for standard set yoghurt.

\subsection{Sensory Evaluation}

Two sensory evaluations was carried out for MIT and standard set yoghurt using trained panellists for descriptive evaluation and consumer panellists for acceptance evaluation. Descriptive evaluation is for the description of both qualitative and quantitative sensory aspects of a product by trained panels, and acceptance evaluation is to assess personal preference by current or potential customers of a product (Meilgaard, Civille, \& Carr, 2007).

Descriptive evaluation

Advertisements were posted and "Sensory Evaluation Panel Interest Survey" forms were distributed to students and staff at Massey University to gauge the interest of people in taking part in descriptive evaluation. Nineteen out of thirty people (called subjects in the following) who were interested and could commit to attending all four sessions (three training and one evaluation session) were selected by means of a screening test. Each session was carried out in the Food Sensory Laboratory, IFNHH.

\section{Screening test}

A screening test was used to select suitable panellists. The screening test comprised 1) a screening questionnaire, 2) identification of basic tastes and 3) ranking of basic tastes. First, subjects were asked to answer all the questions presented in the screening questionnaire, which comprised questions on health, food habits and knowledge of flavour. Next, the subjects were instructed to (1) identify and (2) rank the basic taste in the individual booth.

For the first test, subjects were asked to identify four solutions of basic taste: sweet, sour, salty and bitter. The basic taste solutions were prepared according to American Standard Test Method (Hootman, 1992) with 2.0\% $(\mathrm{w} / \mathrm{v})$ sucrose for sweet solution, $0.2 \%(\mathrm{w} / \mathrm{v})$ sodium chloride for salty solution, $0.07 \%(\mathrm{w} / \mathrm{v})$ citric acid for sour solution and $0.07 \%$ (w/v) caffeine for bitter solution. Distilled water was used as blank solution with the basic taste solutions.

For the second test, subjects were requested to rank the basic taste (sweet, sour, salty and bitter) with four intensities, from low to high. Each of the basic taste solution was prepared as follows: 0.5, 1.0, 2.0 and $4.0 \%$ $(\mathrm{w} / \mathrm{v})$ sucrose for sweet solution; $0.9,1.8,3.6$ and $6.3 \%(\mathrm{w} / \mathrm{v})$ for salty solution; $0.315,0.63,0.9$ and $1.26 \%(\mathrm{w} / \mathrm{v})$ for both citric acid and caffeine for sour and bitter solution, respectively. In the ranking test, a total of 16 solutions ( 4 basic tastes $\mathrm{x} 4$ intensities) were presented to the subject.

Both test samples were assigned with a 3-digit random code and presented in two trays at the same time to the subject. Subjects were provided with score sheet for identify and rank test to record their finding. Based on the screening test, subjects with minimum score of $75 \%$ on both the identification and ranking of basic taste were selected as the descriptive test panellist.

\section{Training sessions}

The 8 selected panellists were requested to attend three training sessions and one product evaluation session. In the first training session, the panellists were asked to generate possible attributes by examining three yoghurt samples (2 MIT set yoghurts and 1 standard set yoghurt) one at a time. The attributes generated consisted of yoghurt appearance, aroma, texture and taste. For appearance and aroma, all possible attributes were listed by examining the yoghurt surface and smell, respectively. For texture, panellists were required to generate texture attributes assessed with a spoon and in the mouth for two yoghurt conditions: before and after stirring. Ten stirs with a spoon were chosen instead of twenty stirs (Folkenberg, Dejmek, Skriver, \& Ipsen, 2005), because ten were sufficient to break the yoghurt structure producing a smooth texture. For yoghurt taste, the panellists were required to taste a spoonful of yoghurt and list taste attributes.

A consensus was reached on the attributes that were possessed by yoghurt samples by eliminating ambiguous and synonymous attributes. The final attributes were ranked into an order suitable for yoghurt evaluation: 
appearance; aroma; texture assessed with spoon before stirring; texture assessed in mouth before stirring; appearance after stirring; texture assessed with spoon after stirring; texture assessed in mouth after stirring; and taste. Training sessions involved roundtable discussions, and testing of yoghurts in individual sensory booths for evaluation training.

Panellists were trained to evaluate yoghurt samples using the generated attributes and, for each attribute, a $15 \mathrm{~cm}$ line scale anchored on the left with 'absent' and on the right with 'intense'. Certain attributes were anchored differently; for example, colour was anchored on the left with 'white' and on the right with 'cream'.

\section{Yoghurt evaluation}

The yoghurt evaluation was carried out after the panellists had received about $8 \mathrm{~h}$ of training (session 4). The trained panellists were asked to evaluate six yoghurt samples ( 3 yoghurt type in duplicate) in the individual sensory booths. Duplicate samples were presented as replication increases the reliability and the possibility of trained panellists being able to detect differences (Kemp, Hollowood, \& Hort, 2009). Six yoghurt samples were labeled with three-digit randomized codes and were served monadically, with one sample evaluated for five minutes before the next sample was served. Plain water and plain crackers were provided for the panellists to cleanse their palates with. The trained panellists evaluated the samples using $15 \mathrm{~cm}$ intensity scale for 19 attributes (Table 1.2). These attributes were developed earlier during the training session. Panellists were provided with descriptive test score sheet to record their findings.

In the training and evaluation sessions, yoghurt samples that had been kept at 4 to $6^{\circ} \mathrm{C}$ for $48 \mathrm{~h}$ after manufacture were presented to the panellists. The sessions were scheduled every Monday, for 4 weeks, from 9 am to 12 noon, as sensory evaluation should not be conducted after meals or tea breaks to prevent the introduction of bias (Meilgaard, et al., 2007).

Acceptance evaluation

Advertisements were posted around Massey University inviting students and staff to participate in yoghurt acceptance evaluation. Three yoghurt samples (2 MIT set yoghurts and 1 standard yoghurt) were presented to each of 30 participants participant $(n=30)$ in individual booths. This number of participant was sufficient, as Stone, Sidel and Bliebaum (2004) suggested that the ideal number of participants for acceptance testing conducted in the laboratory environment is 25 to 50 . The 30 consumers who participated in the acceptance test comprised $25 \%$ males and $75 \%$ females, with $80 \%$ aged $21-30,13 \%$ aged $31-4$, and $6 \%$ aged 51 and above. The frequency of yoghurt consumption amongst the panellists was $30 \%$ daily, 33\% every three days, $17 \%$ weekly, $10 \%$ fortnightly, $6 \%$ monthly and $3 \%$ who never consume yoghurt.

Participants were requested to evaluate three yoghurt (two MIT yoghurts and one standard yoghurt) samples. For each sample, seven attributes were evaluated which are (1) colour and (2) syneresis for appearance, (3) sour for aroma, (4) softness assessed using spoon and (5) thickness assessed in mouth for texture, (6) sour for taste and (7) overall acceptability. All these attributes were evaluated based on 9-point hedonic scale, anchored on the left with "dislike extremely" and on the right with "like extremely".

Yoghurt samples were labelled with 3-digit random codes and served simultaneously to the participants. Samples were served with plain water and plain crackers to allow panellists to cleanse their palate between samples. Yoghurt samples presented to the participants had been stored at 4 to $6^{\circ} \mathrm{C}$ for $48 \mathrm{~h}$ after manufacture. Participants were provided with acceptance evaluation test core sheet to record their finding.

\subsection{Statistical Analysis}

Two-way analysis of variance (ANOVA) was performed using MINITAB 15 (Minitab Inc., State College, PA, USA) to determine any differences between the yoghurts on the analysis of sensory scores.

\section{Results and Discussion}

\subsection{Descriptive Evaluation}

Based on the sensory screening test, eight panellists were selected for the descriptive evaluation.. The eight panellists consist of 5 male and 3 female, aged from 20 to 40 years. The panellists were required to achieve a minimum correct response of $75 \%$. Stone et al. (2004) have stated a minimum of $65 \%$ correct responses in a screening test as a guideline for selecting participants suitable for training.

In the first training session, set yoghurt attributes with definitions and suitable reference materials were discussed and developed with the panellists. The final 19 attributes were listed in Table 2. The reference materials for specific attributes were presented physically to the panellists during the training session. Generally the attributes are based on previous yoghurt sensory studies (Folkenberg, et al., 2005; Isleten \& Karagul-Yuceer, 
2006). In the second and third training sessions, panellists were required to evaluate three yoghurts (2 MIT set yoghurts and 1 standard yoghurt) using the attributes that had been developed earlier.

Most yoghurt attributes were found to be significantly different $(\mathrm{p}<0.05)$ among the three yoghurt samples except for flowability before stirring, lumpiness after stirring, syneresis after stirring and softness after stirring (Table 3). Significant differences $(\mathrm{p}<0.05)$ between panellists were found for only seven of the nineteen attributes (Table 3). This indicates that panellists were able to agree, for most of the attributes, on their differentiation between the three set yoghurts. Variation between panellists was probably due to several factors such as individual differences in the interpretation of attribute scales, and differences in sensitivity (Bayarri, et al., 2011). There was a significant $(\mathrm{p}<0.05)$ interaction effect between product and panellist for eight attributes. This indicates that differences in the way panellists assessed each of these attributes depended on yoghurt type (Stone, et al., 2004).

A comparison of the mean values of attributes of the three set yoghurts is presented in Table 4 . The two set yoghurts produced as a MIT products were observed by the trained panellists to be significantly different ( $\mathrm{p}<$ 0.05) compared with standard set yoghurt for all attributes except flowability before stirring, flowability after stirring (in the case of MIT yoghurt $(\mathrm{NaCN})$ only),lumpiness after stirring, syneresis after stirring and softness after stirring. These results are in accord with those presented in Table 3, and show that the MIT set yoghurts were different from standard set yoghurt.

Table 2. Attributes and definitions used for sensory profiling of set yoghurts

\begin{tabular}{|c|c|c|c|}
\hline Main attributes & Specific attributes & Definition & $\begin{array}{l}\text { Reference / intensity } \\
\text { (on a scale of } 0 \text { to 15) }\end{array}$ \\
\hline \multirow[t]{3}{*}{ Appearance } & Syneresis & $\begin{array}{l}\text { The amount of free why on the surface of } \\
\text { the yoghurt cup }\end{array}$ & \\
\hline & Smoothness & $\begin{array}{l}\text { Quantity of particles quantified by visual } \\
\text { inspection of the yoghurt surface }\end{array}$ & \\
\hline & Colour & $\begin{array}{l}\text { Visual appearance of the product } \\
\text { ranging from white to cream }\end{array}$ & Milk - 2; Cream - 10 \\
\hline Aroma & Sourness & Basic taste stimulated by acids & \\
\hline \multirow{3}{*}{$\begin{array}{l}\text { Texture with spoon } \\
\text { (before and after } \\
\text { stirring) }\end{array}$} & Syneresis & $\begin{array}{l}\text { The amount of free whey observed in the yoghurt } \\
\text { when sample is scooped and being hold for } 5 \text { seconds }\end{array}$ & \\
\hline & Flowability & Ability of yoghurt to flow & Cream - 15 \\
\hline & Softness & Force required to scoop the sample & Cream - 15 \\
\hline \multirow[t]{2}{*}{$\begin{array}{l}\text { Texture in mouth } \\
\text { (before and after } \\
\text { stirring) }\end{array}$} & $\begin{array}{l}\text { Thickness } \\
\text { Stickiness }\end{array}$ & $\begin{array}{l}\text { Mouth coating } \\
\text { Stickiness perceived in between upper and } \\
\text { lower teeth (bite between teeth) }\end{array}$ & Milk Powder - 15 \\
\hline & Graininess & $\begin{array}{l}\text { Irregularity / grains texture perceived when } \\
\text { tongue is push against the palate }\end{array}$ & Humus - 15 \\
\hline $\begin{array}{l}\text { Appearance after } \\
\text { stirring }\end{array}$ & Lumpy & Lumps observed by visual inspection of the yoghurt & $\begin{array}{l}\text { Porridge - } 15 \\
\text { (reference not presented) }\end{array}$ \\
\hline \multirow[t]{2}{*}{ Taste } & Sourness & Basic taste stimulated by acids & $\begin{array}{l}\text { Citric acid solution }(0.08 \%)-5 \text {; } \\
\text { Citric acid solution }(0.15 \%)-10\end{array}$ \\
\hline & Astringent & The shrinking or drying effect on the tongue surface & $\begin{array}{l}\text { Tea solution (soak } 2 \text { tea bags in } 200 \mathrm{ml} \\
\text { of water for } 1 \text { hour) }-10\end{array}$ \\
\hline
\end{tabular}


Table 3. p-values for the effect of yoghurt formulation on yoghurt attribute, for differences between panellists in assessing attributes, and for yoghurt-panellist interactions

\begin{tabular}{|c|c|c|c|}
\hline Attribute & Yoghurt & Panellist & Yoghurt x Panellist \\
\hline \multicolumn{4}{|l|}{ Appearance } \\
\hline Syneresis & $<0.0001^{*}$ & $0.0584^{\mathrm{ns}}$ & $0.2451^{\mathrm{ns}}$ \\
\hline Smoothness & $0.0103 *$ & $0.0642^{\mathrm{ns}}$ & $0.0026^{*}$ \\
\hline Colour & $<0.0001 *$ & $0.3171^{\mathrm{ns}}$ & $0.0025^{*}$ \\
\hline \multicolumn{4}{|l|}{ Aroma } \\
\hline Sourness & $<0.0001 *$ & $0.1435^{\mathrm{ns}}$ & $0.3226^{\mathrm{ns}}$ \\
\hline \multicolumn{4}{|c|}{ Texture assessed with spoon before stirring } \\
\hline Syneresis & $0.0023^{*}$ & $0.3224^{\mathrm{ns}}$ & $0.005^{*}$ \\
\hline Flowability & $0.5218^{\mathrm{ns}}$ & $0.0012 *$ & $<0.0001 *$ \\
\hline Softness & $0.0009^{*}$ & $<0.0001 *$ & $0.0525^{\mathrm{ns}}$ \\
\hline \multicolumn{4}{|c|}{ Texture assessed in mouth before stirring } \\
\hline Thickness & $0.0001^{*}$ & $0.3278^{\mathrm{ns}}$ & $0.3677^{\mathrm{ns}}$ \\
\hline Stickiness & $<0.0001^{*}$ & $0.0011^{*}$ & $0.3017^{\mathrm{ns}}$ \\
\hline Graininess & $<0.0001 *$ & $0.3617^{\mathrm{ns}}$ & $0.1264^{\mathrm{ns}}$ \\
\hline \multicolumn{4}{|c|}{ Appearance after stirring } \\
\hline Lumpy & $0.4059^{\mathrm{ns}}$ & $0.0008^{*}$ & $0.1050^{\mathrm{ns}}$ \\
\hline \multicolumn{4}{|c|}{ Texture assessed with spoon after stirring } \\
\hline Syneresis & $0.0502^{\mathrm{ns}}$ & $<0.0001 *$ & $0.1105^{\mathrm{ns}}$ \\
\hline Flowability & $0.0123^{*}$ & $0.0623^{\text {ns }}$ & $0.0002 *$ \\
\hline Softness & $0.1368^{\mathrm{ns}}$ & $0.0001 *$ & $0.1188^{\mathrm{ns}}$ \\
\hline \multicolumn{4}{|c|}{ Texture assessed in mouth after stirring } \\
\hline Thickness & $<0.0001^{*}$ & $0.1028^{\mathrm{ns}}$ & $0.4973^{\mathrm{ns}}$ \\
\hline Stickiness & $<0.0001^{*}$ & $0.0071^{*}$ & $0.5942^{\mathrm{ns}}$ \\
\hline Graininess & $0.0023^{*}$ & $0.0679^{\mathrm{ns}}$ & $<0.0001 *$ \\
\hline \multicolumn{4}{|l|}{ Taste } \\
\hline Sourness & $<0.0001^{*}$ & $0.1261^{\mathrm{ns}}$ & $0.0002 *$ \\
\hline Astringent & $<0.0001 *$ & $0.9311^{\mathrm{ns}}$ & $<0.0001 *$ \\
\hline
\end{tabular}

An asterisk (*) indicates significant differences are present at $\mathrm{p}<0.05(95 \%$ confidence interval); $\mathrm{ns}=$ not significant.

The two MIT set yoghurts were similar to one another: 15 of the 19 attributes evaluated were not significantly different $(p>0.05)$ between them. The four attributes observed to be different were apparent syneresis, syneresis before stirring, thickness before and thickness after stirring, and flowability after stirring. On the basis of these differences, the set yoghurt fortified with $\mathrm{NaCN}$ was observed to be better than the yoghurt fortified with MPC. Yoghurt containing $\mathrm{NaCN}$ exhibited less apparent syneresis, less syneresis before stirring, a lower flowability after stirring, and a thicker gel both before and after stirring than did the MPC fortified yoghurt. Syneresis is one of the challenges in set yoghurt production (Lee \& Lucey, 2010). The more syneresis that is present the lower the yoghurt quality. The flowability and softness of both MIT yoghurts increased on stirring. This result is in line with Folkenberg et al. (2005), who reported decreasing gel strength caused by the partial breakdown of the protein network due to stirring, as the integrity and coherence of the protein network contributes to gel strength.

The difference between the three set yoghurts is visualized by means of a radar chart in Figure 1 . The red line $(0.2 \%$ STLA MPC) and green line $(0.002 \%$ STLA NaCN) have similar patterns, confirming the similarity between the two MIT yoghurts. In contrast, the blue line (standard set yoghurt) has a very different pattern for many of the attributes. The two MIT set yoghurts were observed to produce more syneresis, and to have a smoother appearance and a whiter colour than the standard set yoghurt. The attributes of texture measured before stirring with a spoon appear not to differ among the three set yoghurts according to the radar chart (Figure 1), but actually the MIT set yoghurts produced somewhat more syneresis, and were softer and had greater flowability than the standard set yoghurt (Table 4). The same observation can be made in regard to the textural attributes evaluated after stirring with a spoon.

Texture assessment in mouth before and after stirring showed that both MIT set yoghurts had less thickness, stickiness and graininess than standard yoghurt. The aroma and taste assessments revealed that the MIT set yoghurts were less sour than standard set yoghurt. This is in accord with $\mathrm{pH}$ measurement: the MIT set yoghurts 
had a higher $\mathrm{pH}(\mathrm{pH} 4.38$ for both) than the standard set yoghurt ( $\mathrm{pH} 3.68)$. The lumpiness of the three set yoghurts after stirring was almost the same. Lumpiness is due to protein aggregates of 1 to $5 \mathrm{~mm}$ present in yoghurt (Isleten \& Karagul-Yuceer, 2006).

Table 4. Mean values of sensory attributes (ranging from 0 to 15 , arbitrary units), and fisher's least significant differences between means (indicated by superscripts)

\begin{tabular}{lccc}
\hline Attributes & \multicolumn{3}{c}{ Samples } \\
\cline { 2 - 4 } & $\begin{array}{c}\text { Standard } \\
\text { Set Yoghurt }\end{array}$ & $\begin{array}{c}\text { MIT Set Yoghurt } \\
(\text { MPC) }\end{array}$ & $\begin{array}{c}\text { MIT Set } \\
\text { Yoghurt (NaCN) }\end{array}$ \\
\hline Appearance & & & \\
Syneresis & $3.03^{\mathrm{c}}$ & $10.10^{\mathrm{a}}$ & $7.89^{\mathrm{b}}$ \\
Smoothness & $11.60^{\mathrm{b}}$ & $12.6^{\mathrm{a}}$ & $12.99^{\mathrm{a}}$ \\
Colour & $11.24^{\mathrm{a}}$ & $3.20^{\mathrm{b}}$ & $3.28^{\mathrm{b}}$ \\
\hline Aroma & & \\
Sourness & $12.91^{\mathrm{a}}$ & $3.03^{\mathrm{b}}$ & $4.64^{\mathrm{b}}$ \\
\hline Before stirring: texture assessed with spoon & & \\
Syneresis & $1.66^{\mathrm{c}}$ & $4.34^{\mathrm{a}}$ & $3.11^{\mathrm{b}}$ \\
Flowability & $0.12^{\mathrm{a}}$ & $0.30^{\mathrm{a}}$ & $0.24^{\mathrm{a}}$ \\
Softness & $7.72^{\mathrm{b}}$ & $10.21^{\mathrm{a}}$ & $9.81^{\mathrm{a}}$ \\
\hline Before stirring: texture assessed in mouth & & \\
Thickness & $11.22^{\mathrm{a}}$ & $4.48^{\mathrm{c}}$ & $6.76^{\mathrm{b}}$ \\
Stickiness & $7.62^{\mathrm{a}}$ & $1.80^{\mathrm{b}}$ & $2.66^{\mathrm{b}}$ \\
Graininess & $5.99^{\mathrm{a}}$ & $1.93^{\mathrm{b}}$ & $2.23^{\mathrm{b}}$ \\
\hline After stirring: Appearance & & \\
Lumpy & $9.20^{\mathrm{a}}$ & $8.60^{\mathrm{a}}$ & $9.60^{\mathrm{a}}$ \\
\hline After stirring: texture assessed with spoon & & \\
Syneresis & $0.80^{\mathrm{a}}$ & $1.18^{\mathrm{a}}$ & $1.33^{\mathrm{a}}$ \\
Flowability & $7.62^{\mathrm{b}}$ & $10.10^{\mathrm{a}}$ & $7.46^{\mathrm{b}}$ \\
Softness & $10.47^{\mathrm{a}}$ & $11.38^{\mathrm{a}}$ & $10.57^{\mathrm{a}}$ \\
\hline After stirring: texture assessed in mouth & & \\
Thickness & $11.33^{\mathrm{a}}$ & $5.20^{\mathrm{c}}$ & $6.97^{\mathrm{b}}$ \\
Stickiness & $8.23^{\mathrm{a}}$ & $2.50^{\mathrm{b}}$ & $3.11^{\mathrm{b}}$ \\
Graininess & $6.23^{\mathrm{a}}$ & $2.73^{\mathrm{b}}$ & $3.76^{\mathrm{b}}$ \\
\hline Taste & $13.65^{\mathrm{a}}$ & $2.68^{\mathrm{b}}$ & $3.10^{\mathrm{b}}$ \\
Sourness & $9.25^{\mathrm{a}}$ & $2.17^{\mathrm{b}}$ & $2.81^{\mathrm{b}}$ \\
Astringent & $5<0.05)$ & \\
\hline
\end{tabular}

${ }^{\mathrm{ab}} \mathrm{M}$ Means within a row with common superscripts are not significantly different $(\mathrm{p}<0.05)$

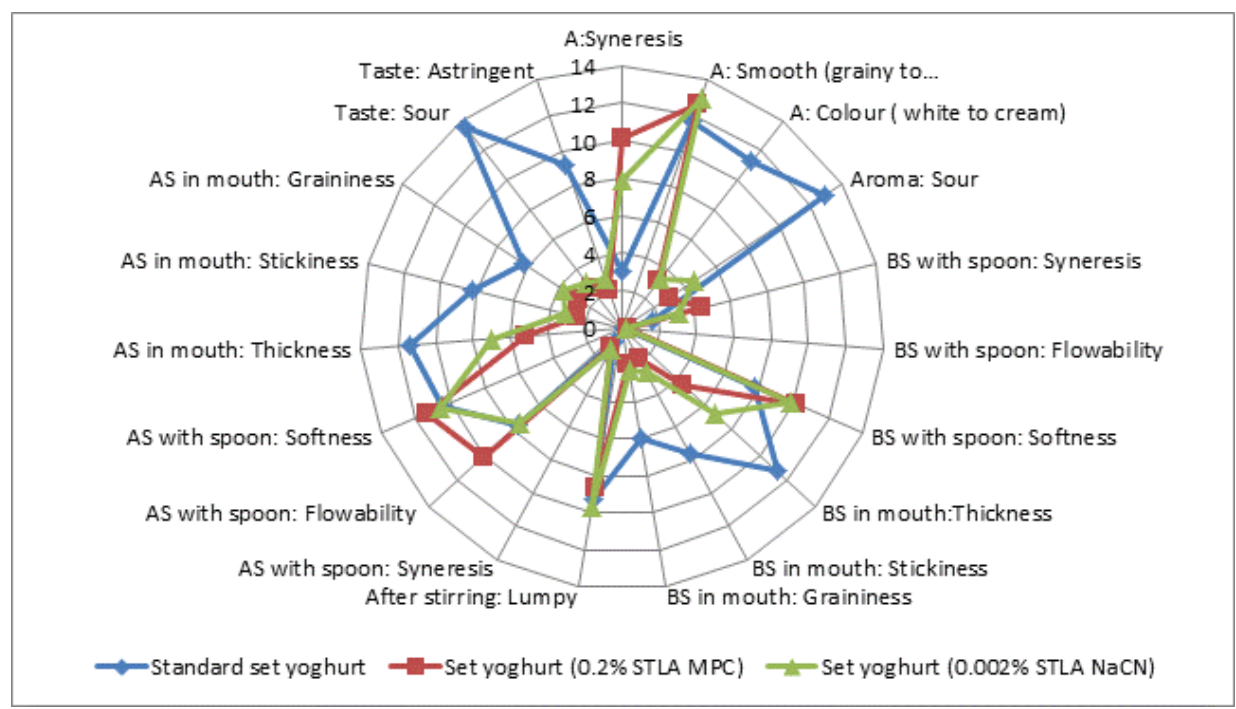

Figure 1. Radar plot of evaluated sensory attributes of three set yoghurts: standard set yoghurt $(2.0 \%(\mathrm{v} / \mathrm{v})$ of STLB; blue), MIT set yoghurt ( $0.2 \%$ (v/v) of STLA using milk protein concentrate (MPC); red) and MIT set yoghurt $(0.002 \%(\mathrm{v} / \mathrm{v})$ of STLA using sodium caseinate $(\mathrm{NaCN})$; green). "A" denotes appearance, "BS with spoon" denotes texture assesed with spoon before stirring; "BS in mouth" denotes texture assessed in mouth before stirring; "AS with spoon" denotes texture assessed with spoon after stirring; "AS in mouth" denotes texture assessed in mouth after stirring. 


\subsection{Acceptance Test}

The sensory acceptance test was carried out for the same three set yoghurts: the standard set yoghurt and the two MIT set yoghurts (Figure 2). The attributes used for this acceptance test were mainly derived from the principle component analysis (PCA) (data not shown), which highlighted the attributes that had a major influence in differentiating the three yoghurts. The thirty consumers who participated in the acceptance test comprised $25 \%$ males and $75 \%$ females, with $80 \%$ aged $21-30,13 \%$ aged $31-4$, and $6 \%$ aged 51 and above. The frequency of yoghurt consumption amongst the panellists was $30 \%$ daily, $33 \%$ every three days, $17 \%$ weekly, $10 \%$ fortnightly, $6 \%$ monthly and $3 \%$ who never consume yoghurt.

The results are presented in Figure 2. The degree of liking for all seven attributes was found to be similar for the two set yoghurts for MIT product except for the sour aroma, where the yoghurt fortified with MPC produced a significantly $(\mathrm{p}<0.05)$ higher liking score. The comparison of the attribute based on preference between the two MIT set yoghurts and the standard set yoghurt, produced no significant difference $(p<0.05)$ except for two attributes: the sour taste and overall acceptability. The MIT yoghurts were significantly more acceptable than the standard yoghurt in term of these two characteristic. The overall acceptability was scored a bit higher for yoghurt fortified with MPC yet there was no significant different $(\mathrm{p}<0.05)$ between both MIT set yoghurts. In one study by Isletan and Karagul-Yuceer (2006), yoghurt fortified with $\mathrm{NaCN}$ received a higher preference rating than yoghurt fortified with whey protein isolate (WPI) and a control yoghurt (fortified with SMP).

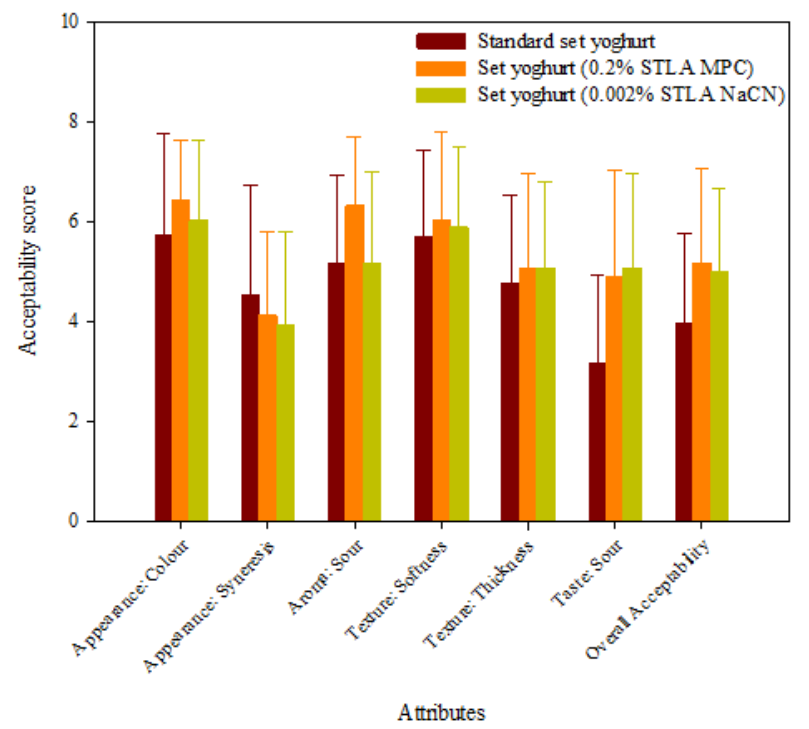

Figure 2. Acceptability scores ${ }^{\mathrm{a}}$ for three set yoghurts: standard set yoghurt $(2.0 \%(\mathrm{v} / \mathrm{v})$ of STLB), MIT set yoghurt $(0.2 \%(\mathrm{v} / \mathrm{v})$ of STLA using milk protein concentrate (MPC)) and MIT set yoghurt $(0.002 \%(\mathrm{v} / \mathrm{v})$ of STLA using sodium caseinate $(\mathrm{NaCN})) .{ }^{\mathrm{a}}$ All values are based on a 9-point hedonic scale, where $1=$ dislike extremely and $9=$ like extremely. Internal bar $= \pm(2 \mathrm{x}$ sample standard deviation $)$.

\section{Conclusion}

Sensory evaluation based on descriptive evaluation revealed similar attributes for the two MIT set yoghurts, yet these were significantly different $(\mathrm{p}<0.05)$ from the standard set yoghurt. MIT set yoghurts scored better than the standard set yoghurts for overall acceptance. Yoghurts produced with $0.002 \%$ (v/v) STLA fortified with $\mathrm{NaCN}$ and with $0.2 \%(\mathrm{v} / \mathrm{v})$ STLA fortified with MPC are acceptable for MIT products.

\section{References}

Bayarri, S., Carbonell, I., Barrios, E. X., \& Costell, E. (2011). Impact of sensory differences on consumer acceptability of yoghurt and yoghurt-like products. International Dairy Journal, 21(2), 111-118. https://doi.org/10.1016/j.idairyj.2010.09.002

Bock, J., Milliken, G., \& Schmidt, K. (2008). Best mixing practices to minimize the particle size in reconstituted nonfat dry milk. Journal of Food Processing and Preservation, 32, 60-74. https://doi.org/10.1111/j.1745-4549.2007.00164.x

Folkenberg, D. M., Dejmek, P., Skriver, A., \& Ipsen, R. (2005). Relation between sensory texture properties and 
exopolysaccharide distribution in set and in stirred yoghurts produced with different starter cultures. Journal of Texture Studies, 36(2), 174-189. https://doi.org/10.1111/j.1745-4603.2005.00010.x

Hootman, R. C. (1992). Manual on Descriptive Analysis Testing for Sensory Evaluation. Philadelphia, PA, USA. https://doi.org/10.1520/MNL13-EB

Isleten, M., \& Karagul-Yuceer, Y. (2006). Effects of dried dairy ingredients on physical and sensory properties of nonfat yogurt. Journal of Dairy Science, 89(8), 2865-2872. https://doi.org/10.3168/jds.S0022-0302(06)72559-0

Jaworska, A. (2007). Made in Transit: A Supply Chain Concept for on the Way Growth, Master Thesis, Design Academy Eindhoven, Eindhoven, The Netherlands.

Kemp, S. E., Hollowood, T., \& Hort, J. (2009). Sensory Evaluation A Practical Handbook. Oxford, UK: Wiley-Blackwell. https://doi.org/10.1002/9781118688076

Lee, W. J., and Lucey, J. A. (2010). Formation and Physical Properties of Yogurt. Asian-Australasian Journal Animal Science., 23(9), 1127-1136. https://doi.org/10.5713/ajas.2010.r.05

Lee, W. J., \& Lucey, J. A. (2004). Structure and Physical Properties of Yogurt Gels: Effect of Inoculation Rate and Incubation Temperature. Journal of Dairy Science., 87(10), 3153-3164. https://doi.org/10.3168/jds.S0022-0302(04)73450-5

Meilgaard, M., Civille, G. V., and Carr, B. T. 2007. Sensory Evaluation Techniques: Taylor \& Francis.

Modler, H. W., Larmond, M. E., Lin, C. S., Froehlich, D., \& Emmons, D. B. (1983). Physical and Sensory Properties of Yogurt Stabilized with Milk-Proteins. Journal of Dairy Science, 66(3), 422-429. https://doi.org/10.3168/jds.S0022-0302(83)81809-8

Nor-Khaizura, M.-A.-R., Flint, S. H., McCarthy, O. J., Palmer, J. S., Golding, M., \& Jaworska, A. (2014). Designing Processing and Fermentation Conditions for Long-Life Set Yoghurt for Made-in-Transit (MIT) Product. Journal of Food Process Engineering, 37, 19-26. https://doi.org/10.1111/jfpe.12055

Nor-Khaizura, M.-A.-R., Flint, S. H., McCarthy, O. J., Palmer, J. S., Golding, M., \& Jaworska, A. (2012). Development of made-in-transit set culture yoghurt: effect of increasing the concentration of reconstituted skim milk as the milk base. International Journal of Food Science \& Technology, 47(3), 579-584. https://doi.org/10.1111/j.1365-2621.2011.02880.x

Rohm, H. (1993). Influence of dry-matter fortification on flow properties of yogurt .2. Time-dependent behavior. Milchwissenschaft-Milk Science International, 48(11), 614-617.

Schkoda, P., Hechler, A., \& Hinrichs, J. (2001). Influence of the protein content on structural characteristics of stirred fermented milk. Milchwissenschaft, 56, 19-22.

Schmidt, R. H., Vargas, M. M., Smith, K. L., \& Jezeski, J. J. (1985). The effect of ultrahigh temperature milk processing on yogurt texture. Journal of Food Processing and Preservation, 9(4), 235-240. https://doi.org/10.1111/j.1745-4549.1985.tb00723.x

Soukoulis, C., Panagiotidis, P., Koureli, R., \& Tzia, C. (2007). Industrial Yogurt Manufacture: Monitoring of Fermentation Process and Improvement of Final Product Quality. Journal of Dairy Science., 90(6), 2641-2654. https://doi.org/10.3168/jds.2006-802

Stone, H., Sidel, J. L., \& Bliebaum, R. (2004). Sensory Evaluation Practices: Elsevier Science.

Tamime, A. Y., \& Robinson, R. K. (2007). Tamime and Robinson's Yoghurt Science and technology (Third Edition ed.). Boca Raton: Woodhead Publishing Limited and CRC Press LLC.

https://doi.org/10.1533/9781845692612

\section{Copyrights}

Copyright for this article is retained by the author(s), with first publication rights granted to the journal.

This is an open-access article distributed under the terms and conditions of the Creative Commons Attribution license (http://creativecommons.org/licenses/by/4.0/). 